\title{
A Tale of Two Navies: Building the Canada-United States Cold War Naval Relationship
}

\section{Peter T. Haydon}

En contraste saisissant avec le NORAD, l'entente de défense maritime Canada-États-Unis n'a jamais été politique. Les deux sous-ensembles du plan de sécurité de base Canada-États-Unis ont porté sur des questions similaires: armes soviétiques nucléaires, le contrôle américain des opérations sur le continent, la souveraineté du Canada, une infrastructure partagée, et une foule d'autres éléments essentiels d'un système de sécurité bilatéral. Pourtant, les politiciens canadiens et les médias (qui prétendent représenter le peuple) ont payé presque aucune attention aux questions continentales de sécurité maritime. Pourquoi? Une des raisons est que les Canadiens généralement ne sont pas intéressés par les choses maritimes en dépit du fait que le Canada est, géographiquement et économiquement, une nation maritime. Culturellement, le Canada a un état d'esprit continental qui exclut joyeusement la dimension maritime du pays, sauf face à la catastrophe ou la malfaisance. Le problème avec cette myopie est que les réussites concernant les océans sont toujours négligés. Cet article raconte l'histoire d'un tel succès: les rapports de travail très efficaces entre les marines canadienne et américaine pendant la guerre froide.

Too many Canadian politicians and members of the media believe that the Canada-United States naval relationship was 'cooked up' in a dark place out of their sight and thus should be viewed with great suspicion. That view is very wrong. In reality, it is a working relationship that has made both strategic and business sense since 1945, when the wartime bilateral continental security agreement was extended to cover the complex post-war international situation. As one would expect, though, the relationship had its 'ups and downs' over the years but always came back to a comfortable state of equilibrium. Although high-level politics played a role at times, mainly over highlycharged issues like access to nuclear information and Arctic sovereignty, the navy-tonavy relationship remained professional and immune to the friction created at higher political levels.

Unlike NORAD, the Canada-United States maritime defence relationship never became political. This is rather strange because both were subordinate plans of the Canada-United States Basic Security Plan (BSP) and dealt with similar issues: Soviet

The Northern Mariner/Le marin du nord XXIV, Nos. 3 \& 4 (Jul. \& Oct. 2014), 176-194 Canadian Military History 23, Nos. 3 \& 4 (Summer \& Autumn 2014), 176-194 
nuclear weapons, American control of continental security operations, Canadian sovereignty, shared infrastructure, and a host of other essential elements of a bilateral security system. Why didn't Canadian politicians and the media pay attention to continental maritime security issues? There are several reasons, one of which is that, although Canada is geographically and economically a maritime nation, Canadians are not particularly interested in maritime activities. Essentially, Canada has a continental mind-set that happily shuts out the maritime dimension of the country except in the face of disaster or perceptions of political incompetence. Another reason is that continental air defence is about boundaries and sovereignty and draws in the very complex issue of political consultation, whereas bilateral naval contingency plans are implemented in international waters and therefore have a much lower political profile. From an American perspective, continental air defence invokes images of Pearl Harbor which, as we saw in the aftermath of the September 2001 attacks on New York and Washington, DC, remains a sensitive issue. Americans do not take kindly to those who attack their homeland and tend to respond quickly and violently. Not surprisingly, air defence, and therefore NORAD, tends to dominate bilateral politics to the virtual exclusion of maritime defence. That the attack on Pearl Harbor came from the sea means nought - it was delivered by air.

The problem with this narrow perspective is that success stories involving the oceans and maritime security, writ large, invariably get overlooked. This paper tells the story of the genesis of one such success story: the very effective working relationship between the Canadian and US Navies. Obviously, the full story of that relationship cannot be told in a single paper; it is just far too long and complex. Instead, I will focus on the period between 1946 and 1952 because that was the period when the foundations were laid for a powerful relationship that lasted throughout the Cold War and into the twenty-first century. In this, the way in which continental anti-submarine warfare (ASW) concepts evolved during the period explains a great deal about that unique naval relationship.

The two navies did not forge a close working relationship during the Second World War; they cooperated operationally of necessity, but the Americans tended to see Royal Canadian Navy (RCN) merely as an extension of the Royal Navy despite the insistence of Canadian politicians for a clear separation and national command of national forces. ${ }^{1}$ The Cold War changed all that; the two navies were drawn together of strategic necessity. Yet the Canadians retained their familial relationship with Britain, ${ }^{2}$ and later as the Canadian navy matured it was able to exist comfortably in a three-way relationship. If anything, it was the British who were more concerned by the closeness of the ties with the Americans. ${ }^{3}$

1 W.G.D. Lund, "The Royal Canadian Navy's Quest for Autonomy in the North Atlantic," in James A. Boutilier (ed.), RCN in Retrospect 1910-1968 (Vancouver: University of British Columbia Press, 1982).

2 The Royal Naval Liaison Officer (RNLO) in Ottawa routinely sat in on Canadian Naval Staff meetings and obviously reported results of discussions back to Admiralty. As long as the RCN used British equipment almost exclusively this made sense, because it also made the procurement process simpler.

3 The 'Americanization' of the Canadian Navy in the 1950s and early-1960s, as increasingly 
As time went by, the Canadian political obsession with NATO prevented the country from being drawn too deeply into either camp; NATO essentially became a protective mantle against both Americanization and British imperialism. That political insularity did not extend to the navy, which was comfortable in its relationships with both the Royal and the US Navies.

After 1952 NATO took over most of the responsibility for North Atlantic ASW operations, essentially the security of the transatlantic sea lines of communication. With the creation of NATO's Supreme Allied Commander Atlantic (SACLANT, based in Norfolk, Virginia) as the North Atlantic planning authority, continental maritime security focussed on coastal security. As the Soviet submarine capability grew and included cruise and ballistic missiles, those operations took on greater strategic importance and were conducted further off-shore. Then, as nuclear weapons became part of the American defensive measures, Canada was largely excluded from these operations as a result of selfserving, idealistic politics. ${ }^{4}$ Also, the bilateral relationship was effected in Canada by budget cuts and policy rationalizations instituted by Liberal governments intent on 'doing things differently'. That said though, the working relationship between the two navies remained close, despite different operational concepts and the inevitable cross-border political differences of opinion. Contrary to popular belief, the relationship functioned efficiently outside the NATO framework even though both partners were members of the Alliance.

So, where did it all begin?

\section{In the Beginning...}

Because the Second World War experience influenced how the two countries responded to the Soviet challenge of the Cold War, we need begin the story in the late summer of 1940 with two politicians sitting in a railroad car in a small town in up-state New York. On the evening of 17 August 1940, President of the United States Franklin D.

more and more US Navy equipment and procedures were adopted, is a study unto itself and far beyond the narrow scope of this paper.

4 This too is a story in itself, parts of which have been told in many places. Despite Canada's apparent nuclear allergy the need to remain involved in strategic ASW operations was always acknowledged politically, and Canada continued to be an active partner in the SOSUS network (Sound Surveillance System) and routinely flew maritime patrol sorties in support of that system in the Canadian areas of responsibility. On occasion, surface ships were deployed to investigate SOSUS contacts, as were submarines. For a good general background on SOSUS and the related mechanics of passive acoustics, see: Edward C. Whitman, "SOSUS: The 'Secret Weapon' of Undersea Surveillance," in Undersea Warfare 7:2 (Winter 2005), on-line at: http://www.navy.mil/navydata/cno/n87/usw/issue_25 /sosus.htm, accessed 20 December 2010.

An overview of the Canadian involvement in strategic ASW can be found in John Orr's "Some Policy Aspects of Canadian Involvement in Strategic ASW, 1945-1968," in Richard H. Gimblett and Richard O. Mayne (eds.), People, Policy and Programmes: Proceedings of the $7^{\text {th }}$ Maritime Command Historical Conference (2005) (Ottawa: Canadian Naval Heritage Team, 2008), 183-203. 
Roosevelt and Canadian Prime Minister William Lyon Mackenzie King drew up the Ogdensburg Declaration by which the two countries agreed to undertake the defence of the continent jointly. It was made public the next day. A Permanent Joint Board on Defense (PJBD) was created to "consider in the broad sense the defense of the north half of the Western Hemisphere" and to examine all aspects of joint defence coordination. The next week, the PJBD met in Ottawa for the first time and quickly set about their new task. It was intended to be more of an advisory than an executive body; however, it became a very powerful instrument because each country's chairman had direct access to the political leadership. ${ }^{5}$

The initial motivation for the bilateral defence structure, which is what it became, was as much about American politics and Canadian concerns for independence from Britain as it was about securing the North American continent from German and Japanese attack. Nevertheless, both the European war and Japanese imperialism were potential threats to American and Canadian security particularly should Britain fall. So the need to coordinate defence arrangements was real, and the PJBD was an eminently sensible concept to oversee coordination and, when necessary, to bypass bureaucratic obstacles when high-level political decisions were needed.

PJBD quickly came up with a series of recommendations for improving continental defence based on the unfortunate (although not unrealistic for the autumn of 1940) assumption that Britain would succumb to the Nazi onslaught. But the recommendations were virtually meaningless without a coherent continental defence plan. Such a plan was developed quickly and independently of the PJBD by a joint team of American and Canadian military planners. Called the Joint Canada-US Basic Defence Plan 1940 or Basic Plan No. 1 it was based on the assumption that after the fall of Britain the Germans would begin a systematic advance on North America by securing forward bases in Iceland, Greenland, and then Newfoundland. However, after the Battle of Britain, when it became clear that Britain would survive, tripartite (Britain, Canada, and the United States) planning began for an eventual assault on Nazi-held Europe even though the United States was not formally at war. Then, on 9 August 1941, Roosevelt and the British Prime Minister, Winston S. Churchill, met for the first time aboard the USS Augusta in Placentia Bay off Newfoundland and issued a joint declaration - the Atlantic Charter as it became known -

5 Several good, detailed accounts of the early years of the PJBD especially during the Second World War exist and are summarized by Christopher Conliffe in his article, "The Permanent Joint Board on Defense, 1940-1988," in David Haglund and Joel J. Sokolsky (eds.), The USCanada Security Relationship: The Politics, Strategy, and Technology of Defence (Boulder, CO: Westview Press, 1989), 145-165. Conliffe's article looks at the political dimensions of the relationship. Sean Maloney's privately published paper, Our Defended Borders: A Short History of the Permanent Joint Board on Defence (sic) and the Military Cooperation Committee, 1940 to Present, in a booklet commemorating the $200^{\text {th }}$ meeting of the PJBD in Vancouver 8-9 October 1997, does not go into great operational detail and he tends to follow the herd in focusing on NORAD almost to the exclusion of other aspects of the relationship. The quote is from the Ogdensburg Declaration of 18 August 1940, paragraph 4, which can be found on-line at http://www.lexum.umontreal.ca/ca_us/en/cts.1947.43.en.html, accessed on 22 December 2010. 
on the purposes of the war against fascism. In that declaration, Britain and the United States agreed to defeat "Nazi tyranny" and not to seek territorial gain from the war. The overarching principle was "the right of all peoples to choose the form of government under which they will live." After the war the intent was that the Allies would create "a permanent system of general security." Just as Wilson's Fourteen Points delineated the First World War, so the Atlantic Charter provided the strategic criteria for the Second. ${ }^{7}$ The Charter led to a plan for the war, known as $A B C-1$ with a subordinate plan, Joint CanadaU.S. Basic Defence Plan No. 2, replacing Basic Plan No. 1. After the Japanese attack on Pearl Harbor on 7 December 1941, $A B C-1$ was re-written as $A B C-22$ to include the possible Japanese initial objectives in an attack on North America. The Japanese strategic objectives were thought to be the Aleutian Islands and the Alaska Peninsula, the Juneau-SitkaKetchikan area, the Queen Charlotte Islands, and the Strait of Juan de Fuca. ${ }^{8}$ Those plans provided the framework for Allied operations in both theatres for the duration of the war.

Wartime Canada-US cooperation at an operational level was not always smooth. At the start of the war, the two navies had virtually nothing in common save geography, but concern that the Americans would have to use Canadian waters should Britain fall made the need for cooperation obvious. The Americans accepted that Canada would remain responsible for coastal and port security, but some form of working agreement on operational command and control would be needed for off-shore areas. ${ }^{9}$ The details of the wartime working relationship between the RCN and the USN are laid out impeccably in the official history of the RCN in the war and there is no point here in attempting to summarize those facts. However, a couple of observations are useful in showing how the wartime experience shaped the Cold War relationship.

First, both the Americans and the British needed the Canadians to carry a disproportionate share of the convoy workload despite any concerns over the RCN's operational capability. As the RCN expanded and grew in operational capability, the larger navies came to respect Canadian persistence and courage at sea. Second, although the Americans considered the RCN as a sub-set of the RN, understandably in light of the Canadian exclusive use of British ships, uniforms, training concepts, and jargon, a strong Canadian nationalist sentiment emerged as the Battle of the Atlantic progressed. By the end of the war the Americans had accepted the fact that the RCN was a Canadian rather than a British navy, and this paved the way for the easy navy-to-navy cooperation that allowed Cold War contingency planning for continental maritime security to progress smoothly.

6 Samuel Rosenman (ed.), Public Papers and Addresses of Franklin D. Roosevelt, vol.10 (1938-1950), 314; on-line at: http://usinfo.org/docs/democracy/53.htm, accessed 20 December 2010.

7 Ibid.

8 Maloney, "Our Defended Borders," op .cit.

9 W.A.B. Douglas, Roger Sarty and Michael Whitby, No Higher Purpose: The Official Operational History of the Royal Canadian Navy in the Second World War, Volume II, Part I, 1939-1943 (St. Catherines, ON: Vanwell Publishing, 2002), 133. 


\section{Post-War Realism}

After the war both countries decided to continue the security cooperation process, and the PJBD met again in Montreal in September 1945 to discuss the principles of future defence cooperation. Little did they know then that the Cold War would soon descend upon the western world, essentially dividing Europe into two armed camps fuelled by dramatically-opposed ideologies. From the beginning, PJBD was spurred on by the US Joint Chiefs of Staff who sought a new joint continental security regime in their determination not to be caught unawares by a surprise enemy attack as they had in December 1941. In early 1946, the Board created a subordinate planning committee, the Military Cooperation Committee (MCC) to deal with the details of joint military contingency planning from a purely military perspective, allowing the PJBD to deal with political issues.

When the MCC met for the first time at Washington in May 1946 the members discussed a draft concept for future Canada-US military cooperation. Reflecting the belief expressed by Winston Churchill at Fulton, Missouri, on 5 March that an unstable, divided Europe existed which might again require American intervention, the concept outlined a troubling view of a future war against the Soviet Union, but curiously without actually naming that state as the enemy. The military threat to western security was summarized, albeit a little obtusely, thus:

Any power or combination of powers capable of overrunning Europe would of necessity possess a great superiority in manpower and in organized ground and tactical air forces. It is reasonable to assume that such a power would also have a submarine force which could be readily expanded by modern production methods and could embody technical improvements developed by German scientists. ${ }^{10}$

The possibility of an invasion of the United States and Canada was not ruled out, but not given much credibility. On the other hand, attacks by saboteurs and submarine attacks on shipping and ports were seen as very likely. The resulting draft concept of continental defence called for a wide range of military capabilities emphasizing comprehensive forces for air and surface surveillance, air intercept, counter-lodgement, and ASW.

Although the initial bilateral planning documents did not go into detail about the nature of the submarine threat, an assessment of the likely Soviet naval capabilities was prepared in Washington and shared with the Canadian naval members of MCC. ${ }^{11}$ This

10 DHH File 80/540, “An Appreciation of the Requirements for Canada-U.S. Security (No. 1, 23 May, 46)," attachment to minutes of Joint Canada-United States Military Cooperation Committee meeting in Washington, 20-23 May 1946, paragraph 5.

11 One of the structural problems in all aspects of Canadian defence planning is that because Canada has no independent foreign intelligence gathering resources except through diplomats and military attaches, it has to rely on raw threat data gathered by allied intelligence agencies. Since these agencies are often reluctant to share raw data, only assessments and staff analyses usually are shared. This obviously limits the degree of strategic independence in Canadian defence plans. 
assessment formed the basis of a briefing given to the Chiefs of Staff Committee in June 1946 by Captain Horatio Nelson Lay, Director of Naval Plans and Operations. ${ }^{12}$ Lay made the point that even though the Soviets did not have a naval capability equivalent to that of either the United States or Great Britain they had the industrial capacity to build such a fleet. The immediate concern was the Soviet submarine fleet of over 200 relatively new hulls; a far greater capability than that of Germany in 1939. Lay went on to explain that the Soviets had acquired the latest German submarine technology, the Type XXI in particular, which had "a submerged speed of 16 knots, great submerged endurance and ability to charge batteries in a few hours without surfacing or exposing anything more than the comparatively inconspicuous Schnorkel." ${ }^{13}$ He explained that this would change the calculus of ASW and render virtually useless most of the ASW equipment used during the recent war. A longer-term possibility existed that the Soviets would develop nuclear propulsion for submarines and eventually be able to use them as launch platforms for missiles. The modern submarine, Lay emphasized, was difficult to hunt and destroy with the ASW equipment presently available. However, as the Allies discovered in the last war, airborne radar allowed a better chance of detecting snorkelling (snorting) submarines. In this, carrier-borne aircraft would be a major factor in modern ASW. He concluded

It must be expected therefore that Russia will devote considerable effort to the development of her submarine force. With the knowledge of German developments which they have acquired and the assistance which will be available from German personnel, Russia will shortly be able to carry out very effective submarine operations against our overseas and coastal shipping and her force may be expected to increase rapidly. ${ }^{14}$

This threat assessment and the related operational implications soon made their way into Canadian naval force planning. A March 1947 naval staff review of future naval force requirements was based on an assumption that another European and North Atlantic war involving the Soviet Union was very possible. ${ }^{15}$ It was also assumed that the Soviet Union would exploit captured German submarine technology and would use its new submarine capability quickly and resolutely. The problem, the review emphasized, was that the higher speed and greater endurance of modern submarines presented the RCN with a major operational challenge. New concepts of ASW were needed using ships, aircraft and systems that had not yet been developed fully. The operational value of the aircraft carrier as one of the main tools in modern ASW was, in naval minds, unassailable - a view that was to be challenged before much longer.

Predictably, contingency planning moved ahead quickly and in lock-step with research and development on new ASW systems and fast escorts. There was also

12 LAC, RG24, Acc 83-4/167, Vol. 8067, File NSTS 11270-15-7 Vol. 2, Captain H.N. Lay, "Russia's Naval Capabilities," Presentation to Chiefs of Staff Committee, 7 June 1946.

13 Lay, "Russia's Naval Capabilities". Interestingly, Lay used US Navy terminology; the RN referred to that procedure as 'snorting'.

14 Lay, "Russia's Naval Capabilities".

15 LAC, RG24, Acc 83-84/167, Vol. 455, File 1650-26, Pt. 2, Memorandum from DNPI to DCNS, "Planning of Post-War Navy," 14 March 1947. 
considerable emphasis placed on assessing the effective strength of the Soviet submarine fleet which was hampered by the lack of adequate intelligence. Under Stalin, the Soviet Union was a closed and repressive society in which the punishment for passing information to 'enemies of the state' was meted out quickly and violently. Reliable intelligence was enormously difficult to obtain and analysis comprised slowly piecing together shards of information gleaned from a wide range of sources.

Of the many questions that needed answering was the rate at which the Soviets would exploit the German submarine technology. The Americans initially tended to be generous, believing, despite a marked lack of knowledge about the Soviet submarine service, that:

the Soviets, a continental power like Germany with both limited access to and dependence upon the sea, would focus their maritime efforts on interdicting Allied sea lines of communication by deploying a large force of modern submarines. $^{16}$

The British, on the other hand, tended to be more cautious in estimating the time the Soviets would need to exploit the German technology, but the RN did not face the same sort of political scepticism as their American counterparts. The process was made even more complicated in the United States by bureaucratic 'turf wars' with accompanying reluctance, and occasional refusal, on the part of the key departments of Defense and State to share intelligence until 1947 when the CIA entered the fray. The result was a period of sub-standard assessments, as a later (March 2001) CIA conference report explained:

[Raymond L.] Garthoff asserts that CIA analysis, especially of Soviet military affairs in the earliest years of the Cold War, was neither especially stellar nor influential, although this would soon change. At the outset, even though CIA had a voice, the most important judgments regarding Soviet intentions fell to others, especially the US military. When the CIA was established, according to Garthoff, there was a general understanding that the Army, Navy, and the newly created Air Force would exercise primary responsibility for military intelligence. Garthoff argues convincingly that during the 1950s the US military seriously miscalculated the threat posed by Soviet forces. He cites as examples of underestimation: the growth of Soviet military expenditure in the mid-1950s, the size of Soviet Army ground forces, the number of Soviet medium bombers, and the availability of uranium and U-235. The US military overestimated the growth of the Soviet submarine force and the production of Soviet long-range bombers. ${ }^{17}$

16 Owen R. Cote, Jr., The Third Battle: Innovation in the U.S. Navy's Silent Cold War Struggle with Soviet Submarines, Naval War College Newport Paper No. 16 (Newport: Naval War College, 2003), 15.

17 "Introduction and Overview of Conference Papers," in Gerald K. Haines and Robert E. Leggett (eds.), Watching the Bear: CIA's Analysis of the Soviet Union, 1947-1991, at https://www.cia.gov/library/center-for-the-study-of-intelligence/csi-publications/books-andmonographs/watching-the-bear-essays-on-cias-analysis-of-the-soviet-union/intro.htm, accessed 20 December 2010. 
Owen J. Cote summarizes the American over-assessment of the submarine threat very well in his excellent monograph, The Third Battle:

Viewed over the same five year period between the end of World War II and Korea, the Soviet Navy's exploitation of the Type XXI lagged significantly behind US Navy intelligence forecasts, which initially foresaw in 1946 a force of 300 Soviet Type XXI equivalents by 1950. It was not until 1949 that the first postwar Soviet submarine designs went to sea. Two classes were deployed, the Whiskey and the Zulu. The Zulu was a true Type XXI, equipped with a snorkel, capable of 16 knots submerged, and possessing the size, habitability, and range necessary for long range, blue water interdiction operations. But only 21 Zulus were commissioned between 1949 and 1958. During the same period, 236 Whiskeys were commissioned, but the Whiskey was a smaller, less capable, shorter range boat, designed more with an eye toward coastal defense and European littoral operations. Furthermore, it was not until the mid-1950s that Whiskeys were even given snorkels. Certainly the Soviet Navy was showing an emphasis on submarines during this period, but it neither deployed them in the numbers nor the quality expected. ${ }^{18}$

Without credible threat information, building a realistic plan to counter the threat and determining the related force requirements were impossible tasks except in the most general of terms, but this did prevent serious speculation on future Soviet submarine capabilities with correspondingly high force requirements to counter the perceived threat. As one would expect, there was much political scepticism of the naval threat assessments and related force requirements.

\section{Cold War Plans Take Shape}

By the beginning of 1947, most of Eastern Europe had fallen under Soviet domination, and it was becoming clear that the rest of Europe, including Britain, Greece and perhaps the Middle East might also be at risk. ${ }^{19}$ The situation was greatly compounded by Britain's painful decision in February that it could no longer support Greece and Turkey in their fight against communism. President Truman's message to Congress on 12 March 1947, which became known as the Truman Doctrine, declaring that the United States would in future "support free peoples who are resisting attempted subjugation by armed minorities or by outside pressures," ${ }^{20}$ established beyond doubt that the United States was not about to see the whole of Europe turned into a Soviet satellite. In this, Canada agreed. The Truman Doctrine thus unequivocally put in motion the mechanism by which the Americans and their allies would oppose the spread of communism. The Canada-United States regional security plan was part of that mechanism. Whatever residual reservations Canadian politicians held at that point ceased to be significant in the larger scheme of things. Yet, the

18 Cote, The Third Battle, 16.

19 The long story of the systematic subversion of Central Europe by the USSR is told well by Louis J. Halle, The Cold War as History (New York: Harper \& Row, 1975), and also by Martin Walker, The Cold War: A History (New York: Henry Holt \& Company, 1995). 
Canadian view of world events was still not sufficiently pessimistic to change fiscal priorities; this would come later.

Cuts to the Canadian defence budget were announced in February 1947. If the Americans were exasperated by the Canadian reluctance to help shoulder the burden of upholding democracy, they had sound reason. But at the same time, the Canadian naval staff was moving ahead with plans for a new force structure based on what was essentially agreed bilateral intelligence on the future direction of the Soviet Navy:

Intelligence estimates indicate with some certainty that the optimum Naval potential of Russia lies in the field of the submarine weapon. It is known that following the end of European hostilities she was at considerable pains to obtain the latest data and specifications on German submarine research, and has been recruiting numbers of ex-U-boat personnel and German scientists connected with U-boat development and construction. While the development of this weapon will not be entirely to the neglect of surface forces the emphasis will, nevertheless, be on submarines which will be of the most modern and effective type.

A consideration of the probable strategy that will be followed in a future war indicates that the lines of communication will, in general, be similar to those of the last war. It can be expected that Russia will be fully alive to the importance of those lines of communication and that a considerable part of her effort will be directed towards their disruption.

It can be further expected that she will not be blind to the lessons of the last war and that her effort against those lines of communication will be applied in full strength from the start of hostilities and not, as Germany did in the last war, at slowly increasing tempo. ${ }^{21}$

In other words, the view was that the next war would largely be a re-run of the last one but with the Russians driving the U-Boats and taking good advantage of all available new technologies.

The accuracy of the threat estimates were not the only obstacle with which American and Canadian naval planners had to contend. On both sides of the border the Chiefs of Staff remained sceptical over their staff's assessments, as did their political masters. It would take the February 1948 Soviet-engineered coup in Czechoslovakia to focus political minds on the reality of the deteriorating situation in Europe. Even then, there were concerns that the planning process was likely to call for unrealistic and unaffordable military capabilities.

The approval of the Canada-United States Basic Security Plan (BSP) in 1947 triggered a complex process for its implementation that was politically difficult largely because of the lack of available funds: demobilization and post-war economic reconstitution requirements took precedence. ${ }^{22}$ In October 1947, the Canadian Chiefs of

21 LAC, RG24, Acc 83-84/167, Vol. 455, File No. 1650-26, memorandum from DNPI to DCNS, "Planning of Post-War Navy," 14 March 1947, paragraphs 9-11.

22 This essentially took place at the same time as the promulgation of the Truman Doctrine and the March 1947 synchronized joint announcements in Ottawa and Washington on the 
Staff submitted to the Cabinet Defence Committee a series of modest proposals for implementing the BSP and begin work on the related operational plans. ${ }^{23}$ The assessment of the new international situation was cautious, to say the least, in reflecting the optimistic views of the Department of External Affairs that the Soviet Union would not deliberately provoke a war with the West. However, the likelihood of conflict through miscalculation, especially if the Soviets attempted to take advantage of any economic instability in Western Europe, was not ruled out. Under those circumstances, it was the collective view that any attack on North America would be diversionary in order to delay the transatlantic reinforcement of Europe. The bulk of the proposals focussed on mapping and charting northern Canada, and preparing for a series of forward operating bases as part of a counterlodgement strategy. Naval proposals were extremely modest: conversion of one destroyer to an ASW escort and a general upgrading of fleet ASW capability. ${ }^{24}$ There was also a call for the beginning of "Joint Maneouvers [sic] and development of new and improved materials, weapons, and operating techniques." ${ }^{25}$ Specifically:

Environmental research, training and planning upon which to build a complete plan for the protection of sea lines of communication. Research and development of improved equipments for anti-submarine warfare; training of anti-submarine personnel in surface ships, aircraft and submarines; and training of personnel in air defence of naval and merchant shipping. ${ }^{26}$

By early 1948 contingency planning was progressing rapidly and there was military staff agreement on the nature of the threat. In February, the MCC drafted two naval appendices to the newly agreed Basic Security Plan (BSP) for submission to the Chiefs of Staff Committee in Ottawa and to the Joint Chiefs of Staff in Washington for approval. The initial Canadian force requirements for the first, covering "Sea Lines of Communication," were rather arbitrary and largely based on an assumption of considerable Soviet effectiveness through new submarine designs. The problem, the planning staffs explained, was that $R \& D$ had not yet produced effective countermeasures to the strategic use of submarines for launching guided missiles against shore targets. Perhaps this statement reflected the tendency to over-estimate the Soviet ability to develop new weapons systems. Tactically, it was assumed that the best way of protecting the sea lines of communication was to take offensive action rather than rely on defensive operations in home waters. In later years, this would prove to be a very controversial strategy and created a dividing line between Canadian and American approaches to strategic ASW. As the navy's briefing to the Canadian Chiefs of Staff explained, the plan emphasized ASW

commitment to bilateral continental defence.

LAC, RG24, Acc 83-84/167, Vol. 8067, File NSTS 11270-15-1 (Vol. 1), Chiefs of Staff Committee Memorandum to Cabinet Defence Committee, "Canada-United States Basic Security Plan Implementation Programme - Fiscal Year 1948-49," 15 October 1947. For more details, see Peter T. Haydon "The RCN's Destroyer Force, 1945-1955," in Gimblett and Mayne (eds.), People, Policy and Programmes, 207-227. COSC Memorandum to Cabinet Defence Committee, 15 October 1947, op. cit., Annex "A", paragraph 20 . 
research and development, building-up infrastructure, and embarking on a program of joint and combined training to establish common operational procedures that included surveillance of remote areas and acquiring adequate intelligence. The naval forces needed to carry out these operations were enormous and far beyond the means of the meagre Canadian defence budget. ${ }^{27}$

The second appendix, entitled "Mobile Striking Forces," essentially a counterlodgement plan, was presented in March. Originally intended to include only air and land forces it was broadened when it became clear that amphibious operations would have to be conducted as part of the counter-lodgement operations. It was anticipated that enemy objectives might be the destruction of outlying military installations and the establishment of enemy facilities in their place as well as the delivery of saboteurs and conducting diversionary attacks. Again, the size of the forces needed to implement the plan was of concern to the Chiefs of Staff. ${ }^{28}$ Although those actual appendices were to be short lived because they would be integrated into a new family of NATO plans for the North Atlantic and more geographically constrained plans for the protection of North American coastal waters, their underlying strategic and tactical concepts would survive. The general weakness of both naval appendices was that they attempted to do too much with too little and created strategic requirements that were unsustainable. Simply, the cost of full bilateral maritime defence was more than the public purse would support.

With the clarity of perfect hindsight, one can see that both navies were a little vulnerable; they had essentially 'hung their hats' on the need to counter the evolving Soviet submarine threat but had done so without a firm foundation of sound intelligence. Not surprisingly, political scepticism ran high. The warning signs that the whole concept of bilateral planning was too rich for the defence budgets of either country started to emerge in early 1948. In March of that year the MCC warned both the American and Canadian Chiefs of Staff that implementing the BSP would be a problem because the force requirements were so large that it was necessary to review its fundamental concepts. ${ }^{29}$ For instance, in protecting sea lines of communication, the problem was one of designing and building modern ASW vessels in sufficient numbers to counter the threat. Because of the lead-time and cost involved, resolving this problem required further study of the basic concepts of maritime defence; the Second World War concepts simply were not going to

27 DHH 73/1223, minutes of COSC meeting No. 414, 12 February 1948, paras 14/15. The force requirements had originally been agreed by the Combined Planners and at that time amounted to approximately 52 small carriers and 967 escort vessels for all escort shipping requirements, plus hunter/killer groups. These estimates included all escort requirements within arbitrarily established Canada-US areas. DHH 73/1223, minutes of COSC meeting No. 417, 2 March 1948, para 4.

29 US National Archives and Records Administration (NARA), State Department Records RG59, "PJBD", Box 25, "Report by the Canada-United States Military Cooperation Committee to the Chiefs of Staff, Canada and the United States, on Implementation Measures for the Canada-United States Basic Security Plan for the Period from 1 April 1949 to 30 June 1950" (MCC 100/4 dated 18 March 1948). The four appendices were: Air Interceptor and Air Warning; Air Photography, Hydrographic Survey, Mapping and Charting; Protection of Sea Lines of Communication; and Signal Communications. 
work against modern submarines.

That summer, the new Chief of the Army Staff in Washington, General Omar Bradley, expressed his concern that the continental defence plans were out of proportion with the threat in calling for more US capabilities than in reality should be devoted to defending North America. ${ }^{30}$ Bradley was not alone in voicing his concerns over the deepening complexity of the naval plans; the US Joint Strategic Plans Committee was also recommending a change in the concept for the protection of shipping:

\begin{abstract}
Although protection of overseas shipping outside of coastal waters may be vital to the defense of Canada and the United States, in the broadest sense, forces for protection of overseas convoy routes should not be charged to the defense of Canada and the United States. Overseas LOC's will be utilized primarily for the development and support of offensive operations in overseas theatres. Therefore, it is considered that the responsibility for so large a portion of the North Atlantic and the provision of the necessary forces for the protection of the sea LOC's therein should not be developed within the framework of the CanadaU.S. Basic Security Plan. Rather, such a responsibility should be a matter for combined British-Canadian-U.S. consideration. ${ }^{31}$
\end{abstract}

This change in concept was accepted, probably to the enormous relief of the Canadian politicians, but that did not change the assessment of the threat. However, most analysts had agreed that Soviet capability would peak in about 1956. The view of the submarine threat was two-fold: first, anti-shipping, in the Atlantic and Pacific much along the same lines as the Second World War; and second, strategic, to launch attacks on North American coastal facilities and land 'special' forces. Again, 1956 was seen as a capability peak when the captured German technology would be fully exploited. It was, in fact, a pretty reasonable estimate even though it did not take into account Stalin's influence on fleet planning that constrained the development of the longer-range submarines. ${ }^{32}$ It would not be until after Stalin's death in March 1953 that Nikita S. Khrushchev, installed as Premier in 1955, authorized the building of the submarine force that defined much of the

30 NARA, Records of the Chief of Naval Operations, Box "Strategic Plans - Canada," internal staff memorandum from Captain H. D. Riley USN (Op-30X), 8 April 1948.

31 NARA, Records of the JCS (RG218) CCS 092 (9-10-25) Ser. 11, "Report by the Joint Strategic Plans Committee to the Chiefs of Staff on Protection of Sea Lines of Communication Appendix to Canada-United States Basic Security Plan" (J.C.S. 1541/52), 31 July 1948.

32 Jürgen Rohwer and Mikhail Monakov, "The Soviet Union's Ocean-Going Fleet, 1935-1956”, in The International History Review 18:4 (Nov 1996), 837-868, explains this: "Stalin, telling Kuznetsov that 'you produce fears for yourself,' also questioned the need for so many different types of submarines. He prohibited big submarines except for forty Project 611/ Zulu-class vessels, preferred the medium submarines of Project 613/ Whiskey-class, and planned to make up the numbers by building small submarines to the last pre-war design, Series XV, followed by the more modern Project 615 / Quebecclass." As further explained, "At the time of Stalin's death in March 1953, of all the ships and submarines he approved after the end of the Second World War, ... forty-three small submarines of Series XV/Project 96 / M-F-class, twenty-six big submarines of Project 611 / Zulu-class, 215 medium submarines of Project 613/ Whiskey-class, thirty-two small submarines of Project 615 / Quebec-class, and one experimental submarine of Project 617 had been laid down." 
North American and western European naval force planning for the remainder of the Cold War.

In September 1948 a draft appreciation of Soviet capabilities and strategy for the period 1949-56 was circulated by the MCC for comment. ${ }^{33}$ Under a scenario that saw the Soviet Union systematically seeking to dominate the world, the assessment was that it would not achieve full military strength until about 1956, but would have a considerable war-making capability before then and would be quite capable at any time of launching a surprise attack against North America in conjunction with an assault into western Europe. Soviet offensive capability, especially by air and submarine, would increase steadily as they exploited new technologies: atomic weapons; submarine-launched guided missiles with a range of 400-500 nautical miles; long-range bombers; and the ability to insert special forces (Spetsnaz) to carry out sabotage and demolition operations against North American targets - primarily military and those essential to reinforcement shipping.

Even though the planners correctly identified the key capabilities, they still tended to give the Soviets more capacity for innovation than realistic in some cases; in others they under-estimated the speed at which new weapons could be developed. For instance, they thought that the first atomic detonation would take place in 1950 when in fact it happened on 29 August 1949 to the surprise of many. The assessment of the Soviet ability to deploy a missile-firing submarine was influenced in part by American 1947-vintage R\&D in marrying a Regulus cruise missile to a submarine. ${ }^{34}$ The family of Tupolev bombers beginning with the Tu-4 (Bull), which was a copy of the US B-29 Superfortress with the range to reach New York or Chicago, and from 1952 the Tu-95 (Bear) with a range of $8,000 \mathrm{~km}$ and a bomb load of 12 tons, provided a very potent and real threat to North America. Spetsnaz teams had been used effectively during the war and there was no reason to suspect that they would not be used again. The problem was the delivery. Forward operating bases in Canada's essentially empty northland were seen as one option and submarines were seen as a second. Despite political concerns over force levels, the counter-lodgement and ASW tasks were high priority and still required considerable forces.

Regardless, the final version of the BSP, which was not approved until March 1949, contained an appendix called "Protection of Coastal Sea Lines of Communication" with a concept of naval operations limited to the following tasks:

1. Perform escort duties as practicable

2. Make effective all measures designed to secure our ports and harbours, including examination services, defense minefields, port war-signalling stations, nets, booms, local surface patrols, radar, coastal batteries, etc.

3. Minesweep defended ports and their approaches.

33 NARA, Records of the Joint Chiefs of Staff, RG218, CCS092 (9-10-45) Ser. 12, Soviet Capabilities and Strategy Against Canada and the United States, 1949-1956, A.C.A.I. 3, 22 September 1948.

34 The US Navy did not fire a Regulus missile from the USS Tunny until July 1953. It took the Soviets longer to make this concept work; in 1956 an SS-N-3 Shaddock cruise missile with a range of about $500 \mathrm{NM}$ was launched from a Whisky-class submarine. 
4. Conduct anti-submarine patrols and hunter-killer operations as practicable. ${ }^{35}$

The related force table contained requirements for both Canadian and US naval forces that were far smaller than the original concept and, more importantly, bore a more direct relationship to what could actually be provided. That appendix to the BSP would survive in one form or another until 1955 when a major revision of the concept for continental defence was introduced as a result of the change in NATO's overall strategic policy. ${ }^{36}$ The change in continental SLOC protection policy did not mean that the work done in developing comprehensive plans for the protection of ocean shipping was wasted. With the formation of NATO in April 1949 and the subsequent evolution of the NATO strategic and force planning systems, the early work done under the aegis of continental defence quickly became the basic framework for North Atlantic defence planning.

\title{
Implementation and Force Planning
}

One of the more important influences on force planning was the series of ASW conferences hosted by the US Navy after the war ended to which as many as 400 specialists and senior naval officers from the RCN, RN, and USN were invited. The benefits were widespread: information on ASW R\&D was shared as was experience gained in new tactics; and intelligence assessments were shared and discussed. The Fourth ASW Conference, held in Washington in November 1949, was particularly productive. The threat was rationalized to reflect a better estimate of the Soviet Union's industrial capability. This was summarized in a report by one of the RCN delegates:

\begin{abstract}
Although the USSR have at present some 260 submarines, they are divided between the Northern Frontier at Polyarnoe Base, the Baltic, Black Sea and Far East, and only some 60 can be considered capable of operations on the North American coasts. It was estimated that only $9-12$ would be in the Atlantic operational area at any one time. However as Russia produced some 200 submarines from 1936 to 1938 , there is reason to believe that were an all out submarine campaign decided upon, her building capacity is adequate for this. ${ }^{37}$
\end{abstract}

Recent fleet exercises by the Americans and British proved conclusively that ASW training was inadequate and existing equipment virtually useless. This led to a call for more urgency in ASW R\&D especially low frequency acoustic detection, weapons of greater lethality, and vastly improved tactics with greater emphasis on anti-submarine

35 NARA, RG218, CCS 092 (9-10-45) ser. 16, Canada-United States Emergency Defense Plan (MCC 300/1 dated 25 March 1949.

36 This was contained in MC-48 distributed in November 1954. See Michael A. Hennessy, "The RCN and the Post-War Naval Revolution, 1945-1955," and John Orr, "Some Policy Aspects of Canadian Involvements in Strategic ASW, 1945-1955," both in Gimblett and Mayne (eds.), People, Policy and Programmes, op. cit.

37 LAC, RG24, Acc 83-84/167, Vol. 8081, File NSTS: 1271-40 (Vol. 4), "Report on Fourth Anti-Submarine Warfare Conference, November $28^{\text {th }}-$ December $2^{\text {nd }} 1949$, Washington, DC," by Captain A.F. Peers, 9 December 1949. 
submarines and surface-air coordination by day and by night. ${ }^{38}$

As far as R\&D went, the conference essentially removed the veil of secrecy on the issue and put scientists and operators together in a more coordinated search for answers that set bilateral ASW operations on a logical evolutionary path. As a result, a call was made for further innovative thinking in areas such as the use of helicopters in ASW and the development of 'dunking' sonar, more formally known as variable-depth sonar (VDS). As people re-discovered in the 1980s, 'the bear was not ten feet tall', and it was quite possible to counter the advances being made in submarine technology with advances in ASW technology. The great exception to all this was the anticipated submarine-launched ballistic missile. Because the Americans had been able to marry the submarine and the missile they assumed that the Soviets would do the same, but their progress was slower and it would not be until the late-1950s that a credible missile threat could be deployed into North American waters. All of this became the catalyst to an unprecedented era of ASW innovation that swamped the meagre resources of the Canadian navy as it attempted to keep pace. A series of new factors started to drive the naval program:

- $\quad$ the marriage of the modern submarine and the missile;

- NATO's demands for convoy escorts for European reinforcement;

- bilateral and national requirements for forces to support SOSUS operations on the Atlantic seaboard;

- the use of helicopters in ASW; and

- NATO's adoption of a nuclear strategy in 1953-54.

It was not until the naval staff took a step back and systematically re-thought the requirements, and then in 1958 developed an innovative modernization and new construction plan that the necessary fleet restructuring became a reality. ${ }^{39}$ New ships were built, ${ }^{40}$ older ships were modernized, and Canada became involved in the SOSUS system, but funding was

38 As early as 1947 is was obvious that a future war would require a different type of ASW escort; the frigates and corvettes of the Second World War were not going to be able to counter the modern, faster submarines which the Russians would have available in significant numbers. It would take time and political commitment to build a new class of ASW escorts and so the RCN decided that some of the existing destroyers would have to be converted for ASW work. As a result, the Naval Board approved modernization programs that would see Algonquin and Crescent completely modernized as "fast ASW Frigates" along the lines of HMS Rocket, and the anti-submarine capability of all other destroyers improved by the addition of better sonar and a better ASW weapon (the Squid mortar). However, prevailing fiscal constraints meant that this program could only be undertaken gradually and would, in fact, be stretched out over the course of the Korean War.

39 That initiative lead variously to: the integration of ASW helicopters into the fleet and the companion development of the DDH; the fitting of ASROC and VDS to other destroyers; the first fleet support ship (Provider); a plan for air-defence destroyers (the General-Purpose Frigates); and a bold plan to a build half-dozen nuclear-powered submarines.

40 Shipbuilding proposals included the Vancouver-class frigate as a response to NATO and national demands for a coastal escort, and a Mackenzie-class general-purpose destroyer that was eventually scaled-down and approved as a repeat-Restigouche class. 
not sufficient to meet all the bilateral requirements as well as those of NATO.

The formation of NATO in 1949, the establishment of SACLANT in 1952, and the start of coordinated NATO force planning provided a strategic framework that the Canadian politicians could accept. Bilateral maritime defence then focussed on the North American seaboard and on detecting any intrusions by submarines, with integrated concepts of coastal convoying and maintaining secure waterways a clear wartime requirement. Within this concept, procedures for dealing with unidentified submarines became a major problem, much of which stemmed from the lack of political concern for that threat until the late-1950s. That threat was summarized in August 1955 by the Chief of the Canadian Naval Staff, Vice-Admiral DeWolf:

In view of the size of the Soviet submarine fleet and the large proportion of ocean patrol submarines comprising it, it must be considered probable that in the preliminary phase of a nuclear war Soviet submarines will be deployed to positions in Canadian coastal waters from which nuclear armed missiles can be launched against targets within their range to coincide with air attacks on other targets. To achieve simultaneous attacks by sea and air would necessitate the submarines being sailed some days previously in order to make the transit to their launching positions. It is conceivable, therefore, that the first indication of the enemy's war intentions may well be the detection by sound surveillance systems, ships or aircraft of a number of submarines approaching the coasts of Canada. ${ }^{41}$

Politically, the outbreak of the Korean War in June 1950 provided the final piece of evidence that the world had again become a dangerous place and that security needed to be taken seriously because the Soviet Union indeed had global aspirations. So, by mid-1950, the bilateral naval relationship had acquired a much clearer focus built around a series of realistic contingency plans and integrated operations orders. Those plans were practiced regularly and updated to incorporate new assessments of the threat, and new tactics and new systems such as SOSUS and the Sub-Air Barrier Doctrine. ${ }^{42}$ In time, nuclear weapons would be added to the inventory as a necessary counter to a submarine caught in the act of launching missiles. In all of this there was a distinct divide between strategic ASW (countering Soviet submarines armed with strategic weapons) and tactical ASW (countering Soviet submarines attacking allied shipping).

The US Navy still had a large fleet but the post-war re-structuring of the US military (which included the creation of the US Air Force as an independent service and a parallel re-evaluation of national strategy) put several naval concepts at risk. At the heart of this was a December 1949 statement by the Secretary of Defense, Louis Johnson:

There's no reason for having a Navy and Marine Corps. General Bradley tells

41 DHH 73/1223, Draft memorandum to the Cabinet Defence Committee, "Authority to attack unidentified submarines detected within or approaching Canadian territorial waters" (NSTS 18100-1), undated attachment to the minutes of the $456^{\text {th }}$ Naval Board meeting held on 31 August 1955.

42 Described and discussed by Owen Cote in The Third Battle, op cit. 
me that amphibious operations are a thing of the past. We'll never have any more amphibious operations. That does away with the Marine Corps. And the Air Force can do anything the Navy can do nowadays, so that does away with the Navy. ${ }^{43}$

As a result, the US Navy had to fight to retain its carrier capability and the ASW role of carrier-borne aircraft became a key part of the rationale, even though the traditional strike role remained (and remains) key to American naval thinking. The RCN was also struggling for its existence; less because of threats from the air force, although they existed, than from budget cuts and political refusal to take the threat seriously.

In Canada, naval aviation was a highly controversial factor throughout the post-war period. In many ways this also reflected the desire of the RCN to maintain a 'fleet-inbeing' rather than revert to a mobilization capability and was also a firm commitment to the belief that carrier-borne aircraft played a key role in ASW operations. Opposition to the carrier task force and the whole concept of naval aviation ran deep. The Chief of the Air Staff, Air Marshall Curtis, continuously voiced his opposition to Canadian naval aviation stating that it was an unnecessary capability. His views were shared by the Chief of the General Staff, Lieutenant-General Charles Foulkes, who believed that the money spent on naval aviation could be put to better use on other naval capabilities. ${ }^{44}$ The issue came to a head in January of 1950 when the Chiefs of Staff discussed the new five-year plan for the Canadian military. In the midst of the discussion Curtis stated, quite bluntly, that the expenditures made on naval aviation could not be justified because carrier-borne tasks could be carried out just as well by allied navies. He then suggested that the $\$ 25$ million a year being spent on naval aviation could be put to better use on Army and RCAF programs. Foulkes did not disagree. ${ }^{45}$ The Chief of Naval Staff, Vice-Admiral Harold Grant, had to fight single-handed to retain the carrier capability. In essence, the debate was as much over the need for a Canadian naval air capability as it was for a bigger portion of the defence budget for the other two services. The debate continued with a great deal of acrimony throughout that spring. By early March 1950, the consensus within the Chiefs of Staff Committee was that the rationale for a Canadian naval aviation capability would have to be reviewed before any related modernization programs could be approved. ${ }^{46}$ The carrier had been offered to NATO as part of the Canadian contribution and there was a strong belief that it would be inappropriate to renege on that offer so quickly. Perhaps Curtis was merely echoing the views of his USAF counterparts in his continued opposition to the carrier capability. Although the Minister eventually supported the RCN, scepticism of the need for a dedicated naval aviation capability remained despite the proven ASW capability.

43 Quoted in General Charles C. Krulak, USMC, Expeditionary Operations. Marine Corps Doctrinal Publication 3 (PCN 14200000900) (Washington: Department of the Navy, Marine Corps Headquarters, April 1998), 61.

44 DHH 73/1223, minutes of the 3rd meeting of the Chief of Staff Committee (COSC) with the Minister of National Defence on 13 September 1948. Curtis' concern was that the RCN intended to expand its scope of operations to include shore-based ASW and anti-shipping.

45 Minutes of a special meeting of the Chiefs of Staff Committee held on 30/31 January 1950.

46 Minutes of a special meeting of the Chiefs of Staff Committee held on 6 March 1950. 


\section{Conclusion}

Speaking in Indianapolis in October 1953, then-Senator John F. Kennedy said:

Time is only a friend so long as it is favorably used and there are growing indications that in many categories of defense, the years since Korea have enabled the communists to overcome some of their deficiencies in atomic power and, at the same time, continue to widen the gap that separates us on the ground, in the air and under the sea. The evidence is obvious. The armies that the Soviet Union and her satellites have available for an all out attack on the Continent of Europe are several times the size of the force that now guards Western Europe from invasion. According to Admiral Carney, the Navy Chief of Operation, speaking in Boston last Monday, the Soviet Union now is the second greatest naval power in the world and they have surpassed in general naval strength Great Britain. In particular, they have concentrated their effort in the development of the most powerful under sea fleet that the world has ever seen. They have, in fact, five times the submarine fleet with which the Germans nearly succeeded in isolating the British in the early days of the last war and their submarines are infinitely more effective. But dangerous as are these threats to our national security - far greater importance is that presented by the menace of Soviet atomic and hydrogen weapons to the United States. ${ }^{47}$

In hindsight, and somewhat in keeping with the traditional Canadian perception of the dominance of the NATO planning system, it would be easy to overlook the value of the initial bilateral planning process to both countries. On one hand, it made the United States aware of the importance of recognizing the idiosyncrasies of a smaller country, especially where that country did not have comparable experience in strategic planning. This would become even more important in the evolution of NATO where the Americans had to be more open to the concerns of other states. On the other hand, the process allowed Canada to break free from the 'imperial' structure under which its military traditionally functioned. Without this independence, Canada would not have been such an effective member of NATO. Yet on the other hand, Canada also had to realize that collective defence was not a free ride, although it often had to be reminded of this fact in later years. Although the initial joint plans did not survive in their original form, because they were modified to meet changing circumstances, they provided the basis for future cooperation. Most of that cooperation was mutually beneficial, but it would be incorrect to take away the view that on balance Canada was the greater beneficiary. Not only was the Canada-US planning process part of the maturing process for the Canadian navy, it also provided much of the technical base upon which the RCN grew in stature.

47 Kennedy Archives, Extract from a speech by Senator John F Kennedy at the Executive Committee Meeting at the American Legion National Headquarters in Indianapolis, Indiana on October 16, 1953; available on-line at: http://www.jfklibrary.org/Historical+Resources/ Archives/Reference+Desk/Speeches/JFK/JFK+PrePres/1953/002PRESPRES12SPEECHES_ 53OCT16.htm, accessed 21 December 2010. 